Gut, 1966, 7, 164

\title{
Percutaneous cholangiography in the management of biliary stricture
}

\author{
J. G. WALKER, W. B. YOUNG, PHYLLIS GEORGE, AND SHEILA SHERLOCK
}

From the Departments of Medicine, Radiology, and Surgery, Royal Free Hospital, London

EDITORIAL SYNOPSIS The technique of percutaneous cholangiography using a polyethylene tube threaded on to a fine needle and removing the needle as soon as the liver is entered is described, with its advantages and results. Complications are reduced to a minimum if, when a dilated biliary tree is found, operation is carried out the same day, preferably within about two hours.

The biliary tree was successfully outlined in 29 out of 39 instances in patients with strictures of the bile ducts. In none of these cases had the biliary tree been satisfactorily outlined by oral or intravenous cholangiography.

The surgical repair of biliary stricture is almost always a difficult technical problem. If the anatomy of the duct system can be demonstrated before operation, much of the uncertainty is dispelled. Percutaneous cholangiography is here described as a safe and successful technique for this purpose.

Since Huard and Do-Xuan-Hop (1937) first described cholangiography performed by percutaneous liver puncture there have been a number of reports on the procedure, its indications, complications, and limitations. The technique has been used with some success in cases of biliary stricture (Remolar, Katz, Rybak, and Pellizari, 1956; Redington, Fitzgerald, and Knight, 1957; Santos, Figueroa, and López, 1960; Kaplan, Traitz, Mitchel, and Block, 1961 ; Shaldon, Barber, and Young, 1962; Glenn, Evans, Mujahed, and Thorbjarnarson, 1962; Arner, Hagberg, and Seldinger, 1962; Isley and Schauble, 1962; Flemma, Schauble, Gardner, Anlyan, and Capp, 1963; Elkington and Bernstein, 1964; Weichel, 1964; Zinberg, Berk, and Plasencia, 1965). The majority of these general reports, however, deal with only small numbers of patients with biliary stricture and this condition in particular is not discussed. Because of instances of fatal intraperitoneal haemorrhage (Nurick, Patey, and Whiteside, 1953; Darmaillacq and Régnier, 1954), death from bile peritonitis (Leger, Zara, and Wargnier, 1953; Stiris, 1962; Zinberg, et al. 1965), and from biliaemia (Arner et al., 1962), the technique has yet to gain general acceptance in this country.

Early investigators used rigid metal needles of various types and a major advance was the use of a flexible catheter introduced by means of a needle, after which the latter was removed, hence minimizing the chances of subsequent damage to the liver caused by movements. Leger et al. (1953) studied a small number of cases with this technique. It was later developed independently by a number of workers (Fernström and Seldinger, 1956; Wiechel, 1960; Shaldon et al., 1962; Arner et al., 1962) and employed in larger series. The present paper describes the application of percutaneous cholangiography as modified by Shaldon et al. (1962) to the investigation of patients with biliary stricture.

\section{THE TECHNIQUE}

PRINCIPLE A polyethylene tube is threaded on to a fine needle and introduced percutaneously directly into the liver. The needle is at once withdrawn leaving the polyethylene tubing in situ. The end of the tubing is then attached by an adaptor to a syringe. Constant suction is maintained while the tube is gradually withdrawn. Once a duct is entered, bile is aspirated into the tube and syringe. Sufficient $45 \%$ Hypaque (Winthrop) is then injected under radiological screen control to obtain optimum filling of the duct system, and films are taken in various positions to show the site and extent of any obstruction present.

PREPARATION OF THE PATIENT IN THE WARD The prothrombin time is checked and corrected, if necessary, by administration of vitamin $\mathrm{K}$. The patient is tested for sensitivity to the contrast material. The abdominal skin is prepared in the ward and food and drink are withheld on the morning of the procedure. The patient is premedicated with pethidine 50 to $100 \mathrm{mg}$. and scopolamine 0.4 to $0.6 \mathrm{mg}$. 45 minutes before the time of the $x$-ray examination. Tetracycline cover is started the day before the examination and continued for five days. 
PREPARATION OF TUBES AND NEEDLES The tubing used is thin-walled flexible polyethylene of internal diameter $1.5 \mathrm{~mm}$. Short lengths are cut, each approximately $20 \mathrm{~cm}$. long. A flange is made at one end of each of these tubes by rotating the tip over a small flame. The tubes, together with six flexible 20 -gauge steel needles $15 \mathrm{~cm}$. in length, ground with a short-bevel cutting point, and three tap adaptors, are kept pre-sterilized.

A polyethylene tube is taken and drawn, flange first, over one of the needles. While tube and needle are held in one hand, the free end is pulled out so that it is stretched and its calibre reduced until it tightly grips the end of the needle. The tube is cut off flush with the bevel of the needle, and an adaptor threaded over needle and catheter which are now ready for use.

THE PROCEDURE The investigation is performed in the $x$-ray department on a standard tilting screening table. Image intensification is an advantage. A general anaesthetic is used only in children or unduly nervous patients.

The examination is preferably performed by two persons, one of whom intubates the biliary tree while the other operates the image intensifier or fluorescent screen and takes the films. For an anterior injection the site chosen for insertion of the needle is $2 \mathrm{~cm}$. below and $2 \mathrm{~cm}$. to the right of the xiphisternum. This may be varied to avoid old operation scars. Local anaesthetic (1\% lignocaine) is injected into skin, subcutaneous tissues, and down to the liver capsule with the patient holding his breath. For a lateral intercostal approach, a point in the mid-axillary line is chosen over one of the lower right intercostal spaces, below the level of the costo-phrenic angle on full inspiration as shown on preliminary screen examination.

Following a small skin incision a track is made through subcutaneous tissues and muscle using mosquito forceps. This is particularly important if there has been previous abdominal surgery, as scar tissue tends to buckle the polyethylene tube during insertion. With the patient holding the breath, the needle and polyethylene tubing are then introduced rapidly through the prepared track in a slightly cephaled direction, to a depth of approximately $10 \mathrm{~cm}$. and the needle itself is then swiftly withdrawn. The patient may then breathe. The collar adaptor is then connected to a tap connector and a $20 \mathrm{ml}$. syringe containing saline. The system is flushed and the catheter slowly withdrawn as suction is applied.

When a bile duct is entered there is an immediate change of pressure in the syringe and bile, recognized by its colour, is aspirated into the tube. Occasionally the bile is white when a colourless fluid, sticky to the touch, flows up the tube. A few millilitres of bile are always drawn off for culture.

When bile is aspirated the tap adaptor is strapped to the skin and the syringe removed. Now $5 \mathrm{ml}$. of contrast material is injected by way of a further flexible polyethylene cistern. The radiologist operating the screen can see immediately whether it is flowing into the duct system. If it is, the injection is continued until the biliary tree is filled sufficiently to provide maximum information. The patient can be turned, or the table tilted, to demonstrate the anatomy of the ducts as fully as possible and the films are taken in positions seen best to show the site and extent of the stricture. The amount of Hypaque injected varies according to the capacity of the duct system. Often $20 \mathrm{ml}$. is sufficient, but $60 \mathrm{ml}$. or more may be required if there is marked dilatation. If a blood vessel is entered, the catheter immediately fills with blood. This is of no consequence, the tube is flushed with saline and withdrawal continued.

If the tube is completely withdrawn without bile being aspirated, a second puncture is made using a fresh needle and tube, the needle being directed a little to the right of the first puncture. If this fails, yet a different direction of insertion is chosen. If the biliary system is dilated a radicle is usually successfully entered in two or three attempts. However, where the obstruction is believed to be intermittent or partial as many as 10 punctures may be made. To show a high stricture involving the origins of both left and right hepatic ducts it may be necessary occasionally to cannulate both duct systems separately.

If biliary dilatation or obstruction have been demonstrated, then operation should be performed the same day and preferably within two hours. When the diagnosis of stricture has already been made on clinical grounds the operation will probably be undertaken irrespective of the result of the percutaneous cholangiogram. The patient is taken to the operating theatre with the polyethylene tube in place, draining bile into a sterile receiver.

In patients where the clinical diagnosis of stricture is uncertain, a negative cholangiogram provides evidence against there being any biliary dilatation (or obstruction, therefore) and this should be taken into consideration with the clinical findings and biochemical results before a decision to operate is taken. When a dilated radicle has not been entered, it is safe to withdraw the cannula and observe the patient on the ward for a few days (George, Young, Walker, and Sherlock, 1965).

\section{RESULTS}

Thirty-five patients, aged 10 to 68 years, have been studied (Tables I and II). The stricture followed biliary tract surgery in 31 patients, 25 of whom had already undergone one or more explorations for repair of biliary stricture. Four patients (cases 24, $25,32,33$ ) who had not undergone previous surgery gave a long history of symptoms suggestive of cholelithiasis and in every instance operation revealed stones as well as a stricture.

All patients had typical symptoms with intermittent or constant jaundice, upper abdominal pain, fever, pale stools, and dark urine. Serum bilirubin levels were elevated in the majority of cases (Tables I and II), but in 13 instances the serum bilirubin level was less than $2 \mathrm{mg}$. per $100 \mathrm{ml}$. at the time of cholangiography. The serum alkaline phosphatase was always raised. In none of the cases was it possible to demonstrate the main bile ducts satisfactorily by oral or intravenous cholangiography, although in one (case 35 ) the ducts contained gas and could be 
TABLE I

CASES WITH SUCCESSFUL PERCUTANEOUS CHOLANGIOGRAPHY

\begin{tabular}{|c|c|c|c|c|c|c|c|c|c|}
\hline \multicolumn{3}{|c|}{ Patient } & \multirow{2}{*}{$\begin{array}{l}\text { Duration } \\
\text { of Jaundice } \\
\text { (mth.) }\end{array}$} & \multirow{2}{*}{$\begin{array}{l}\text { Serum } \\
\text { Bilirubin } \\
\text { Level }(\mathrm{mg} . \\
\text { per } \\
100 \mathrm{ml} .)\end{array}$} & \multirow{2}{*}{$\begin{array}{l}\text { Alkaline } \\
\text { Phospha- } \\
\text { tase Level } \\
\text { (K.-A. } \\
\text { units per } \\
100 \text { ml.) }\end{array}$} & \multirow{2}{*}{$\begin{array}{l}\text { No. of } \\
\text { Previous } \\
\text { Biliary } \\
\text { Tract } \\
\text { Operations }\end{array}$} & \multirow{2}{*}{$\begin{array}{l}\text { Findings at Percutaneous } \\
\text { Cholangiography }\end{array}$} & \multirow{2}{*}{$\begin{array}{l}\text { Findings at } \\
\text { Laparotomy }\end{array}$} & \multirow[t]{2}{*}{ Operation Performed } \\
\hline No. & Sex & $\begin{array}{l}\text { Age } \\
(y r .)\end{array}$ & & & & & & & \\
\hline 1 & $\mathbf{F}$ & 59 & 6 & $2 \cdot 8$ & 84 & 4 & $\begin{array}{l}\text { Narrowing of chole- } \\
\text { dochojejunostomy; } \\
\text { slight dilatation biliary } \\
\text { tree }\end{array}$ & $\begin{array}{l}\text { Mild stenosis of old } \\
\text { choledochojejuno- } \\
\text { stomy }\end{array}$ & $\begin{array}{l}\text { Dilatation of } \\
\text { anastomosis from below } \\
\text { via jejunum; insertion } \\
\text { polythene splint }\end{array}$ \\
\hline 2 & $\mathbf{M}$ & 60 & $9^{2}$ & 5 & 55 & 3 & $\begin{array}{l}\text { Strictures } R \text {. and } L \text {. } \\
\text { hepatic ducts; calculi in } \\
\text { R. main hepatic ducts }\end{array}$ & As cholangiogram & $\begin{array}{l}R \text {. and } L \text {. hepatic ducts } \\
\text { anastomosed to jejunum } \\
\text { over } Y \text { tube splint }^{3}\end{array}$ \\
\hline 3 & $\mathbf{F}$ & 23 & $2^{2}$ & $1 \cdot 1$ & 100 & 2 & $\begin{array}{l}\text { Stricture common bile } \\
\text { duct with calculi above }\end{array}$ & As cholangiogram & $\begin{array}{l}\text { Choledochojejuno- } \\
\text { stomys }\end{array}$ \\
\hline 4 & $\mathbf{F}$ & 42 & 3 & 21 & 22 & 2 & $\begin{array}{l}\text { Stricture at junction } L \text {. } \\
\text { and } R \text {. hepatic ducts }\end{array}$ & As cholangiogram & $\begin{array}{l}R \text {. and } L \text {. hepatic ducts } \\
\text { anastomosed to jejunum }\end{array}$ \\
\hline 5 & $\mathbf{M}$ & 49 & 1 & 13 & 46 & 1 & $\begin{array}{l}\text { Stricture common bile } \\
\text { duct }\end{array}$ & As cholangiogram & $\begin{array}{l}\text { Excision of stricture and } \\
\text { choledochodochostomy }\end{array}$ \\
\hline 6 & $\mathbf{F}$ & 43 & 1 & 14 & 37 & 2 & $\begin{array}{l}\text { Stricture common } \\
\text { hepatic duct }\end{array}$ & As cholangiogram & $\begin{array}{l}\text { Choledochojejuno- } \\
\text { stomy }\end{array}$ \\
\hline $7 a^{1}$ & $\mathbf{F}$ & 50 & 10 & 8 & 30 & 2 & $\begin{array}{l}\text { Stricture common bile } \\
\text { duct with stones above; } \\
\text { cholecystoduodeno- } \\
\text { stomy stenosed }\end{array}$ & As cholangiogram & $\begin{array}{l}\text { Repair of common bile } \\
\text { duct by end-to-end } \\
\text { anastomosis over a } T \text { - } \\
\text { tube: cholecystectomy }\end{array}$ \\
\hline b & & 52 & $9^{2}$ & $1 \cdot 1$ & 104 & 3 & $\begin{array}{l}\text { Stricture common bile } \\
\text { duct }\end{array}$ & As cholangiogram & $\begin{array}{l}\text { Choledochojejuno- } \\
\text { stomy }^{3}\end{array}$ \\
\hline 8 & $\mathbf{M}$ & 62 & $3^{2}$ & $1 \cdot 2$ & 25 & 2 & $\begin{array}{l}\text { Stenosis } R \text {. hepatic } \\
\text { duct; calculi in conmmon } \\
\text { bile duct }\end{array}$ & $\begin{array}{l}\text { Dilated common bile } \\
\text { duct with calculi and } \\
\text { debris; stenosed } R \text {. } \\
\text { hepatic duct }\end{array}$ & $\begin{array}{l}\text { Dilatation } \mathbf{R} \text {. hepatic } \\
\text { duct; irrigation of } \\
\text { biliary tree; T-tube } \\
\text { drainage }\end{array}$ \\
\hline 9 & $\mathbf{M}$ & 45 & $5^{2}$ & 1.4 & 35 & 1 & $\begin{array}{l}\text { Stricture common bile } \\
\text { duct with irregular } \\
\text { walls }\end{array}$ & $\begin{array}{l}\text { Calculi and debris in } \\
\text { dilated friable } \\
\text { common bile duct } \\
\text { with low stricture }\end{array}$ & $\begin{array}{l}\text { Excision of } 3 \mathrm{~cm} \text {. of } \\
\text { bile duct, choledocho- } \\
\text { jejunostomy }\end{array}$ \\
\hline 10 & $\mathbf{F}$ & 31 & $12^{2}$ & 7 & 285 & 3 & $\begin{array}{l}\text { Stricture common } \\
\text { hepatic duct with } \\
\text { calculi above }\end{array}$ & $\begin{array}{l}\text { Stenosis of old chole- } \\
\text { dochojejunostomy }\end{array}$ & $\begin{array}{l}\text { Reconstruction of } \\
\text { anastomosis }^{3}\end{array}$ \\
\hline 11 & $\mathbf{M}$ & 46 & $2^{2}$ & $1 \cdot 2$ & 32 & 3 & $\begin{array}{l}\text { Strictures R. main and } \\
\text { common hepatic ducts }\end{array}$ & $\begin{array}{l}\text { Stenosis of previous } \\
\text { choledochojejuno- } \\
\text { stomy }\end{array}$ & $\begin{array}{l}\text { Separate anastomosis of } \\
\mathbf{R} \text {. and } \mathbf{L} \text {. hepatic ducts } \\
\text { to jejunum over } \\
\text { polythene splints }\end{array}$ \\
\hline $12 \mathrm{a}^{1}$ & $\mathbf{M}$ & 37 & 3 & 9 & 28 & 2 & $\begin{array}{l}\text { Stricture common } \\
\text { hepatic duct }\end{array}$ & $\begin{array}{l}\text { Stenosed choledocho- } \\
\text { duodenostomy }\end{array}$ & $\begin{array}{l}\text { Choledochojejuno- } \\
\text { stomy }^{2}\end{array}$ \\
\hline$b$ & & 37 & $3^{2}$ & 0.5 & 36 & 3 & $\begin{array}{l}\text { Stricture common } \\
\text { hepatic duct }\end{array}$ & $\begin{array}{l}\text { Stenosed choledocho- } \\
\text { jejunostomy }\end{array}$ & $\begin{array}{l}\text { Reconstruction of } \\
\text { anastomosis over poly- } \\
\text { thene splint }{ }^{3}\end{array}$ \\
\hline 13 & $\mathbf{F}$ & 14 & 36 & 20 & 44 & 2 & $\begin{array}{l}\text { Separate strictures of } \\
\mathbf{R} \text {. and } \mathbf{L} \text {. hepatic ducts; } \\
\text { debris } \mathbf{R} \text {. hepatic duct }\end{array}$ & As cholangiogram & $\begin{array}{l}\text { Excision of strictures } \\
\text { and anastomosis of } \\
\text { ducts to jejunum over } \\
\text { Y-tube splint }\end{array}$ \\
\hline 14 & $\mathbf{M}$ & 49 & $12^{2}$ & $1 \cdot 2$ & 52 & 2 & $\begin{array}{l}\text { Multiple calculi in } \\
\text { common hepatic duct; } \\
\text { stenosed choledocho- } \\
\text { duodenostomy }\end{array}$ & As cholangiogram & $\begin{array}{l}\text { Choledochojejuno- } \\
\text { stomy }^{3}\end{array}$ \\
\hline 15 & $\mathbf{F}$ & 33 & $24^{2}$ & $2 \cdot 1$ & 58 & 2 & $\begin{array}{l}\text { Stricture common } \\
\text { hepatic duct }\end{array}$ & $\begin{array}{l}\text { Stenosed choledocho- } \\
\text { duodenostomy }\end{array}$ & $\begin{array}{l}\text { Choledochojejuno- } \\
\text { stomys }\end{array}$ \\
\hline 16 & $\mathbf{M}$ & 52 & $24^{2}$ & 7 & 90 & 4 & $\begin{array}{l}\text { Stricture junction } \mathbf{R} \text {. } \\
\text { and } \mathbf{L} \text {. hepatic ducts; } \\
\text { slight dilatation of } \mathbf{L} \text {. } \\
\text { hepatic duct system only }\end{array}$ & Not or & perated \\
\hline 17 & $\mathbf{M}$ & 16 & 1 & 28 & 85 & 1 & $\begin{array}{l}\text { Stricture common } \\
\text { hepatic duct }\end{array}$ & As cholangiogram & $\begin{array}{l}\text { Dilatation of stricture; } \\
\text { cholecystectomy }\end{array}$ \\
\hline 18 & $\mathbf{F}$ & 53 & $26^{2}$ & 08 & 100 & 2 & $\begin{array}{l}\text { Narrowing of chole- } \\
\text { dochojejunostomy }\end{array}$ & As cholangiogram & $\begin{array}{l}\text { Dilatation of anasto- } \\
\text { mosis from below via } \\
\text { jejunum and insertion } \\
\text { of polythene splint }\end{array}$ \\
\hline 19 & $\mathbf{F}$ & 49 & 12 & 22 & 22 & 1 & $\begin{array}{l}\text { Dilated cystic duct and } \\
\text { gall bladder; stricture } \\
\text { common bile duct }\end{array}$ & $\begin{array}{l}\text { Occluded cholecysto- } \\
\text { jejunostomy }\end{array}$ & Choledochojejunostomy \\
\hline 20 & $\mathbf{F}$ & 37 & $132^{2}$ & 12 & 85 & 4 & $\begin{array}{l}\text { Stricture common bile } \\
\text { duct; gross dilatation } \\
\text { of biliary tree }\end{array}$ & $\begin{array}{l}\text { Debris and stones in } \\
\text { dilated common bile } \\
\text { duct; stenosed } \\
\text { choledochoduodeno- } \\
\text { stomy }\end{array}$ & Choledochojejunostomy ${ }^{2}$ \\
\hline
\end{tabular}


TABLE I continued

\begin{tabular}{|c|c|c|c|c|c|c|c|c|c|}
\hline \multirow{2}{*}{\multicolumn{3}{|c|}{ Patient }} & \multicolumn{6}{|c|}{ CASES WITH SUCCESSFUL PERCUTANEOUS CHOLANGIOGRAPHY } & \multirow{3}{*}{ Operation Performed } \\
\hline & & & \multirow{2}{*}{$\begin{array}{l}\text { Duration } \\
\text { of Jaundice } \\
\text { (mth.) }\end{array}$} & \multirow{2}{*}{$\begin{array}{l}\text { Serum } \\
\text { Bilirubin } \\
\text { Level ( } \mathrm{mg} . \\
\text { per } \\
100 \mathrm{ml} .)\end{array}$} & \multirow{2}{*}{$\begin{array}{l}\text { Alkaline } \\
\text { Phospha- } \\
\text { tase Level } \\
\text { (K.-A. } \\
\text { units per } \\
100 \text { ml.) }\end{array}$} & \multirow{2}{*}{$\begin{array}{l}\text { No. of } \\
\text { Previous } \\
\text { Biliary } \\
\text { Tract } \\
\text { Operations }\end{array}$} & \multirow{2}{*}{$\begin{array}{l}\text { Findings at Percutaneous } \\
\text { Cholangiography }\end{array}$} & \multirow{2}{*}{$\begin{array}{l}\text { Findings at } \\
\text { Laparotomy }\end{array}$} & \\
\hline No. & Sex & $\begin{array}{l}\text { Age } \\
\text { (yr.) }\end{array}$ & & & & & & & \\
\hline 21 & $\mathbf{F}$ & 27 & 5 & 6 & 42 & 1 & $\begin{array}{l}\text { Stricture common bile } \\
\text { duct }\end{array}$ & As cholangiogram & Choledochojejunostomy \\
\hline 22 & $\mathbf{F}$ & 68 & $24^{2}$ & $0 \cdot 7$ & 24 & 1 & $\begin{array}{l}\text { Stricture lower end } \\
\text { common bile duct; } \\
\text { stones; gross dilatation }\end{array}$ & As cholangiogram & $\begin{array}{l}\text { Transduodenal } \\
\text { sphincterotomy; irriga- } \\
\text { tion of biliary tree and } \\
\text { T-tube drainage }\end{array}$ \\
\hline 23 & $\mathbf{F}$ & 32 & $48^{2}$ & $2 \cdot 6$ & 46 & 2 & $\begin{array}{l}\text { Stricture common bile } \\
\text { duct }\end{array}$ & As cholangiogram & Choledochojejunostomy ${ }^{3}$ \\
\hline 24 & $\mathbf{F}$ & 63 & 6 & 7 & 130 & 0 & $\begin{array}{l}\text { Stricture lower end } \\
\text { common bile duct; } \\
\text { stones; gross dilatation }\end{array}$ & As cholangiogram & $\begin{array}{l}\text { Cholecystectomy; } \\
\text { sphincterotomy; T-tube } \\
\text { drainage }\end{array}$ \\
\hline 26 & $\mathbf{M}$ & 34 & $4^{2}$ & 0.5 & 40 & 1 & $\begin{array}{l}\text { Stricture common bile } \\
\text { duct }\end{array}$ & $\begin{array}{l}\text { Stenosed choledocho- } \\
\text { duodenostomy }\end{array}$ & $\begin{array}{l}\text { Cholecystectomy; } \\
\text { choledochojejunostomy }\end{array}$ \\
\hline 27 & $F$ & 13 & 5 & 3 & 49 & 3 & $\begin{array}{l}\text { Gross dilatation } \\
\text { common bile duct } \\
\text { above stricture }\end{array}$ & $\begin{array}{l}\text { Cystic common bile } \\
\text { duct with stenosed } \\
\text { choledochoduodeno- } \\
\text { stomy }\end{array}$ & $\begin{array}{l}\text { Excision of choledochus } \\
\text { cyst; choledocho- } \\
\text { jejunostomy }\end{array}$ \\
\hline
\end{tabular}

${ }^{1}$ Percutaneous cholangiography successfully performed on two separate occasions.

${ }^{2}$ Intermittent attacks of jaundice for period stated.

${ }^{3}$ Jejuno-jejunostomy also performed in these cases.

seen on plain films. This delineation was not good enough to determine the exact site and extent of the stricture.

\section{SUCCESSFUL CASES}

The findings are summarized in Table I. Cholangiograms were obtained in 27 patients and in two (cases 7 and 12) the procedure was successful on two separate occasions.

The serum bilirubin level was less than $1 \mathrm{mg} . \%$ in four instances and less than $2 \mathrm{mg} . \%$ in a further six. In the remaining 19 instances the level was between $2 \cdot 1$ and $28 \mathrm{mg}$. $\%$.

Local anaesthesia was used in all cases except in two young patients (cases 13 and 27). The anterior approach was used in all but three instances (cases 22,23 , and 26) where the lateral approach was used. In 28 of the successful cholangiograms, one injection outlined the whole of the biliary tree. In one instance (case 13) the obstruction involved the junction of right and left hepatic ducts and initially only the right main duct system was outlined. To visualize the whole of the biliary tree the left main duct system was then intubated by a separate puncture, performed through the same skin incision, but with a different direction of insertion of the second needle and tube.

In 13 instances the stricture was at the site of a previous anastomosis of a major bile duct to bowel.
In nine instances the common bile duct was involved, in two the common hepatic duct, and in five the junction of right and left main hepatic ducts or these ducts individually. In addition, calculi and biliary debris were demonstrated in 10 out of 12 instances where they were subsequently found at operation.

Laparotomy was performed within two hours of the radiological procedure in all instances except one (case 16). Here, the radiographic findings were a very mild dilatation of the left hepatic duct system and a stricture at the junction of the left and right main ducts. The right main duct appeared normal in calibre. The patient had undergone four previous operations and in view of this and the minimal dilatation of the biliary system it was decided that further intervention could achieve little. After the radiological procedure had been completed he was returned to the ward and observed carefully for signs of intraperitoneal haemorrhage or bile leakage. No such signs appeared and he was allowed home after three days.

In the remaining 28 instances the operations performed were as follows (Table I):-Choledochojejunostomy was carried out in 19 instances; in 15 the common bile duct or common hepatic duct was anastomosed to a loop of jejunum and in four the hepatic ducts themselves were anastomosed separately to jejunum, using a Y-tube splint in two instances and separate polythene tube splints in one. 

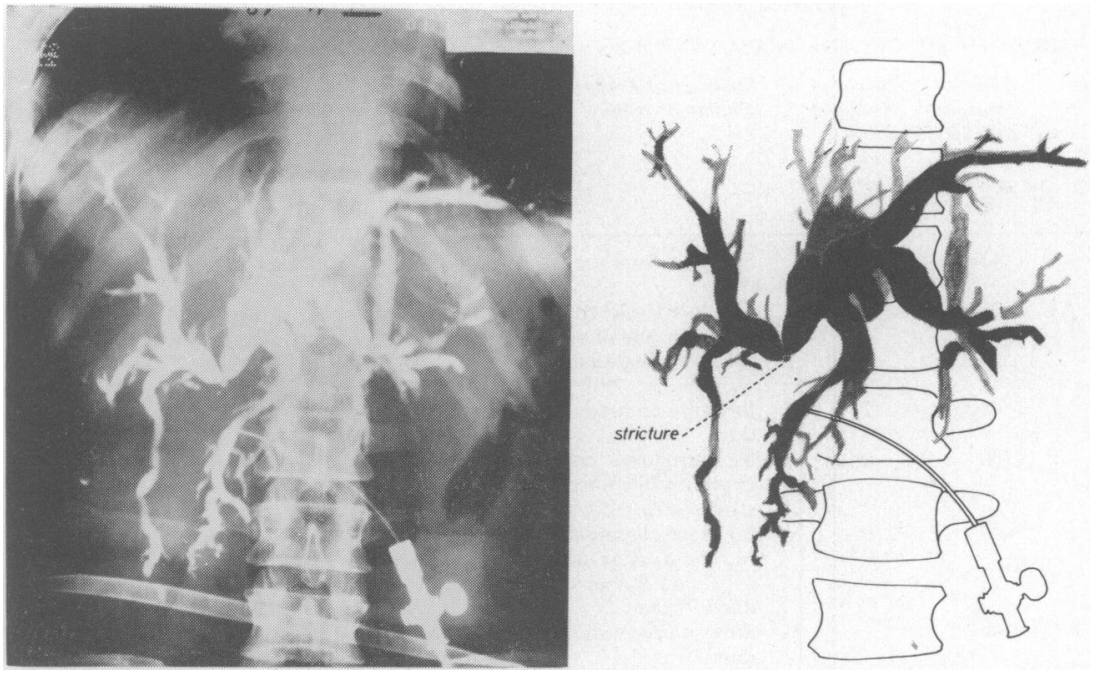

FIG. 1. Stricture completely occluding the common hepatic duct at its bifurcation (case 4). The intrahepatic biliary tree is dilated.

Dilatation with subsequent T-tube drainage was employed in three cases when the stricture was high in the biliary tree and in two cases an existing anastomosis to bowel was dilated from below and a tube splint introduced without actual reconstruction being required. Sphincterotomy was performed in two patients and end-to-end repair of the common bile duct in two cases. In addition to these definitive procedures on the biliary stricture, cholecystectomy was performed at the same operation in four patients.

\section{ILLUSTRATIVE CASE REPORTS}

CASE 4 (TABLE I) In November 1960, a 42-year-old housewife underwent cholecystectomy. Three months later she developed jaundice and itching, and a further laparotomy was performed. The common bile duct could not be located because of very dense scar tissue, and she remained jaundiced. Two months later she was transferred to the Royal Free Hospital. Percutaneous cholangiography revealed a stricture completely occluding the common hepatic duct just below the junction of the right and left main ducts (Fig. 1). At operation, numerous adhesions were found, dilated right and left hepatic ducts were identified and anastomosed to a loop of jejunum. A jejuno-jejunostomy was also performed.

A percutaneous cholangiogram clearly demonstrated the biliary anatomy in a case of postoperative stricture where previous laparotomy had
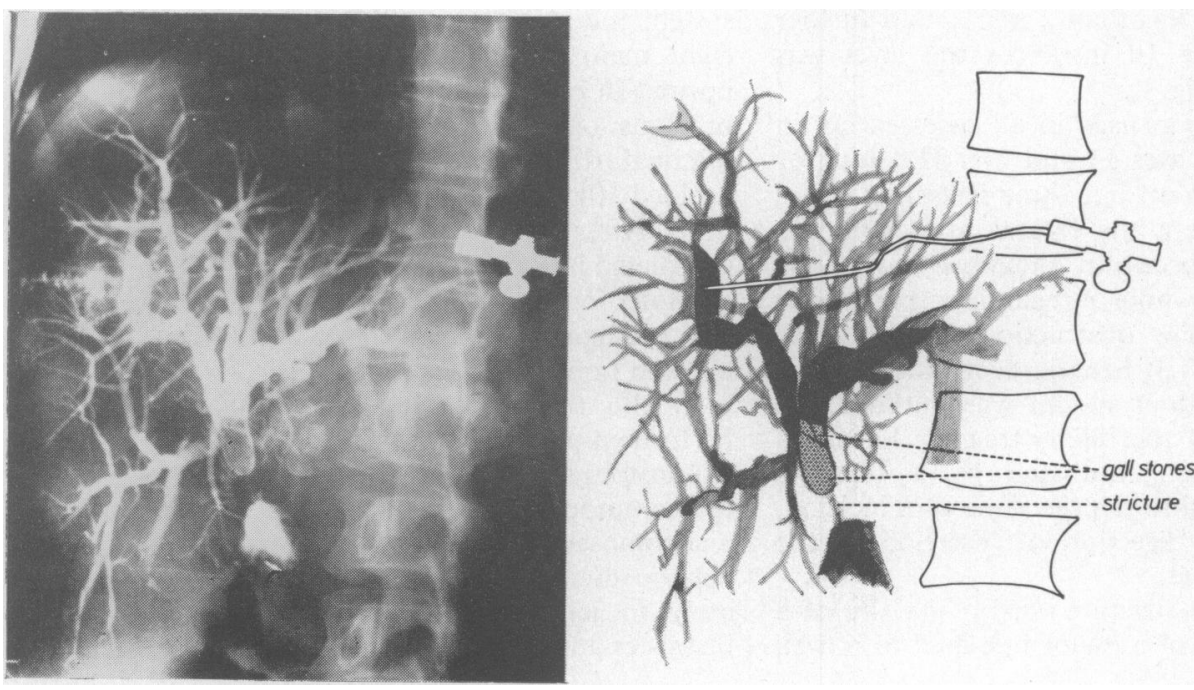

FIG. 2. Stricture

of the common hepatic duct at site of previous anastomosis to bowel (case 10). A little contrast medium has entered the jejunal loop. The biliary tree is dilated and contains calculi. (We are indebted to Mr. Rodney Smith and Professor Sheila Sherlock (editors of 'Surgery of the gallbladder and bile ducts') and to $\mathrm{Mr}$. Rodney Maingot for permission to reproduce this cholangiogram.) 
been fruitless because of dense adhesions. Aided by the radiograph the surgeon was able to proceed directly to exploration of the area of the stricture in the porta hepatis and to perform an anastomosis.

CASE 10 (TABLE I) Following routine cholecystectomy in 1960 , a 30-year-old housewife underwent drainage of a subhepatic abscess and, later, repair of a biliary stricture. For the past year she had suffered bouts of mild jaundice but was unwilling to have a further operation. When it was explained to her that a radiograph could show if she was likely to benefit from further intervention, she consented to the investigation. Percutaneous cholangiography in 1962 showed a tight stricture at the site of previous anastomosis to bowel (Fig. 2). Calculi were present in the common hepatic duct. The previous anastomosis was taken down, biliary lavage performed, and a choledocho-jejunostomy constructed. The patient is well three years later.

The percutaneous cholangiogram allowed a firm decision to be made upon the advisability of surgical
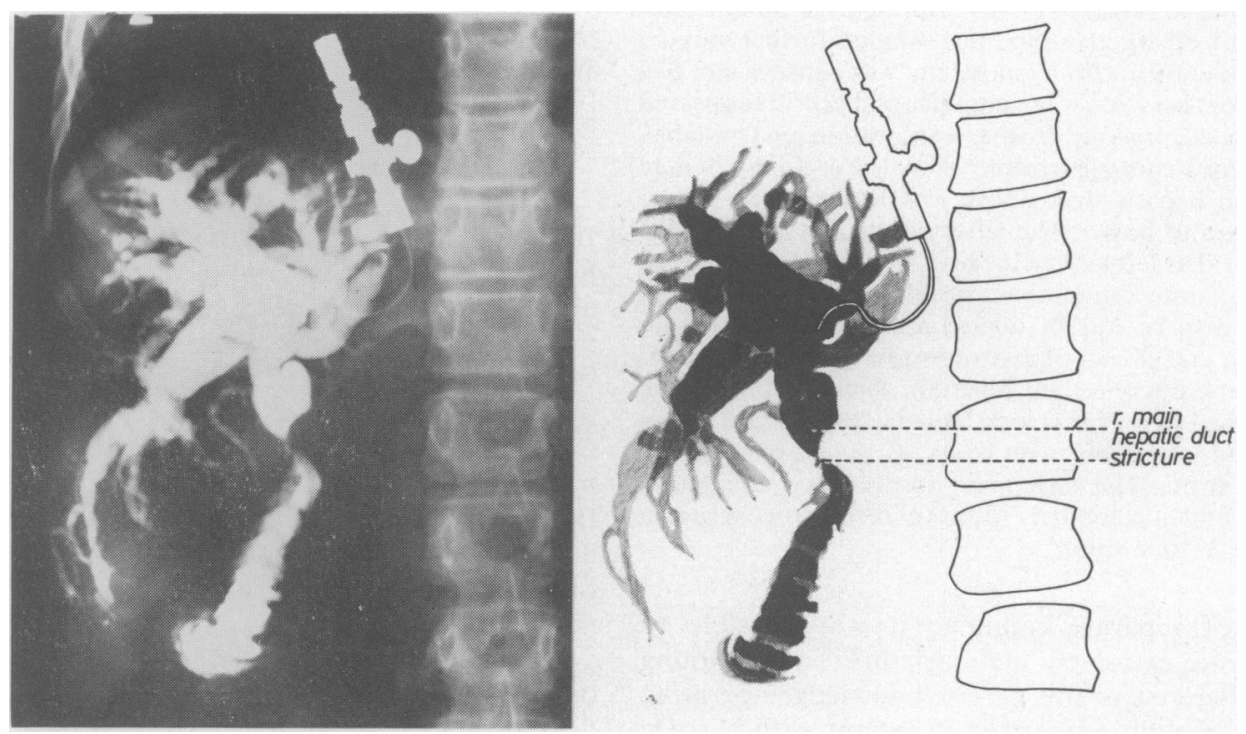

FIG. 3. Stricture of the right main hepatic duct at site of its anastomosis to a loop of jejunum (case 13). Contrast medium has entered the bowel. Marked dilatation of right main biliary tree; no filling of left main duct system.
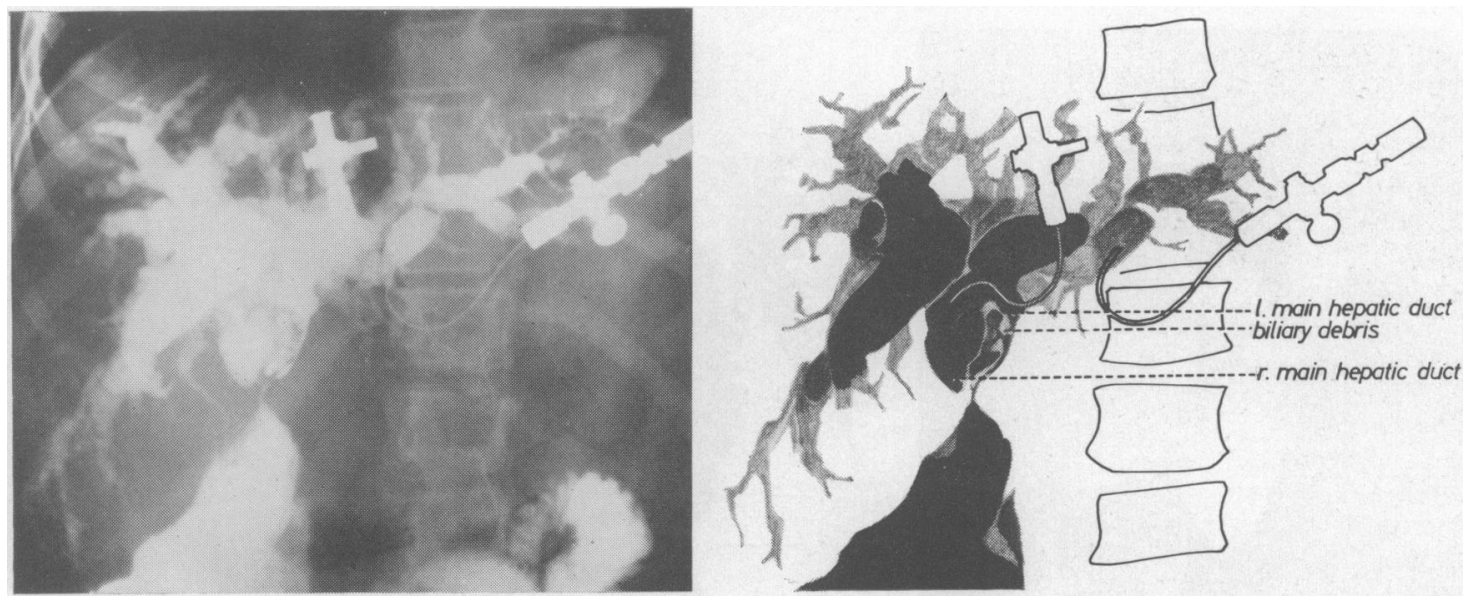

FIG. 4. The left hepatic duct and its branches have now been demonstrated by a separate intubation using a second cannula (case 13). The left main duct system is markedly dilated and there is a stricture at its lower end with small stones above it. Contrast medium has remained in the right lobe following the previous injection (Fig. 3). 
exploration in a patient who had already undergone three operations and was disinclined towards further surgery. Knowing the site of the stricture and that stones also were present, it was possible to decide preoperatively the nature of the operation.

CASE 13 (TABle I) In August 1958, an 8-year-old schoolgirl was found to have portal cirrhosis and oesophageal varices. In 1961, prolonged gastrointestinal bleeding was followed by laparotomy at which a choledochal cyst, 4 in. in diameter and pressing on the portal vein, was discovered. The cyst was excised as radically as possible and portocaval anastomosis performed. A month later jaundice of obstructive type necessitated further surgery and a high choledocho-jejunostomy was constructed. She was well for two years when jaundice and pruritis appeared and persisted, making further exploration unavoidable. Percutaneous cholangiography revealed a grossly dilated right main hepatic duct above a stricture at the site of anastomosis to bowel. The left main duct system did not fill (Fig. 3). The left lobe of the liver was therefore explored using a separate cannula and needle. The left main duct was shown to be equally dilated and to have a stricture at its lower end (Fig. 4). Laparotomy revealed strictures of both hepatic ducts at their junction, where they had been anastomosed to a jejunal loop. Biliary 'sludge' and debris were found in the left main ducts, as predicted from the cholangiogram. The strictures were excised, the ducts irrigated, and anastomoses to bowel reconstructed over a polythene Y-tube splint.

By use of separate cannulae it was possible to demonstrate extremely high strictures in this young patient. Because of this precise knowledge operating time was greatly reduced in a patient with chronic liver disease.
CASE 20 (TABle I) For 11 years a 37-year-old Cypriot woman had suffered intermittent attacks of jaundice and fever. In 1952 she had undergone biliary exploration and, later, cholecystectomy. Afterwards, laparotomy had again been performed because of swinging temperatures, but no details of the operation were available. In 1953 choledocho-jejunostomy had been performed. Percutaneous cholangiography in 1964 revealed a grossly dilated biliary tree and stenosis of the previous anastomosis (Fig. 5). Choledocho-jejunostomy and jejunojejunostomy were performed.

The site of the biliary stricture in this patient who had undergone four previous biliary tract operations was accurately demonstrated. Gross biliary dilatation had resulted from the prolonged obstruction.

\section{UNSUCCESSFUL CASES}

In eight patients percutaneous cholangiograms could not be obtained and in two of these further attempts at cholangiography after an interval of several months were also unsuccessful (Table II). The serum bilirubin level was elevated above $2 \mathrm{mg}$. \% in seven instances (range 3 to $21 \mathrm{mg} . \%$ ) and was less than $2 \mathrm{mg} . \%$ in three instances. In nine instances laparotomy and operative cholangiography were performed. In one patient (case 32) surgical intervention was decided against after failure to cannulate a biliary radicle on the second occasion. The patient suffered no untoward effects.

An explanation for failure was always present. In one of the first patients studied (case 28), when a duct had not been located after three punctures the procedure was abandoned, probably too soon.
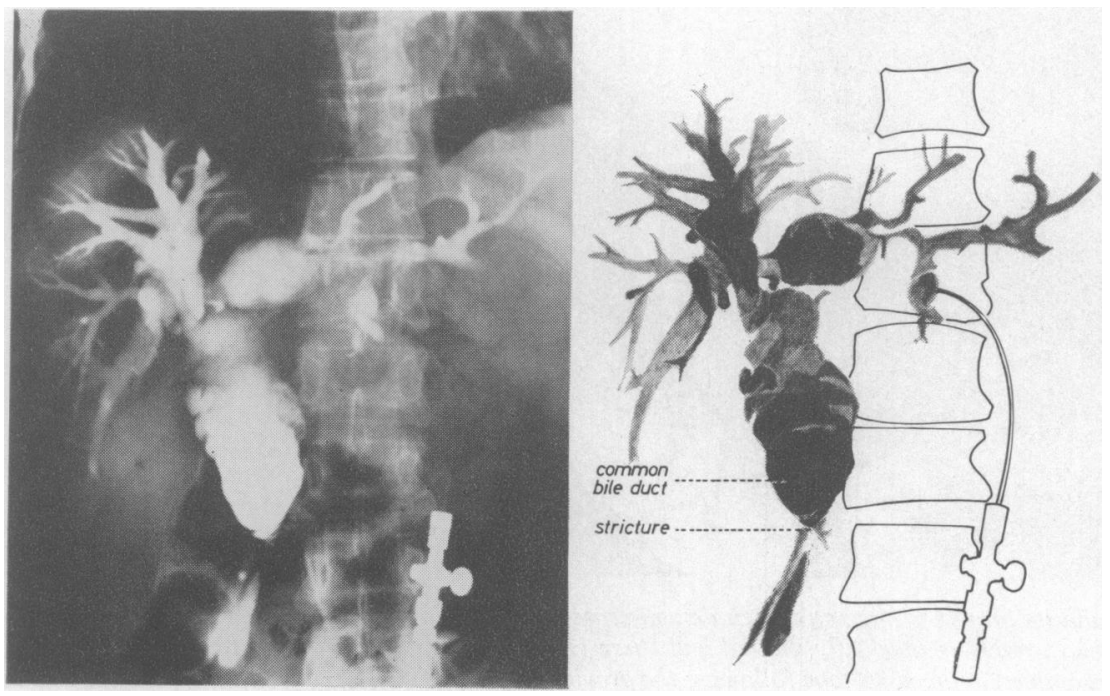

FIG. 5. Gross dilatation of the common bile and hepatic ducts after longstanding obstruction (case 20). A previous anastomosis to the duodenum has become almost totally occluded. 
TABLE II

CASES WITH UNSUCCESSFUL ATTEMPTS AT PERCUTANEOUS CHOLANGIOGRAPHY

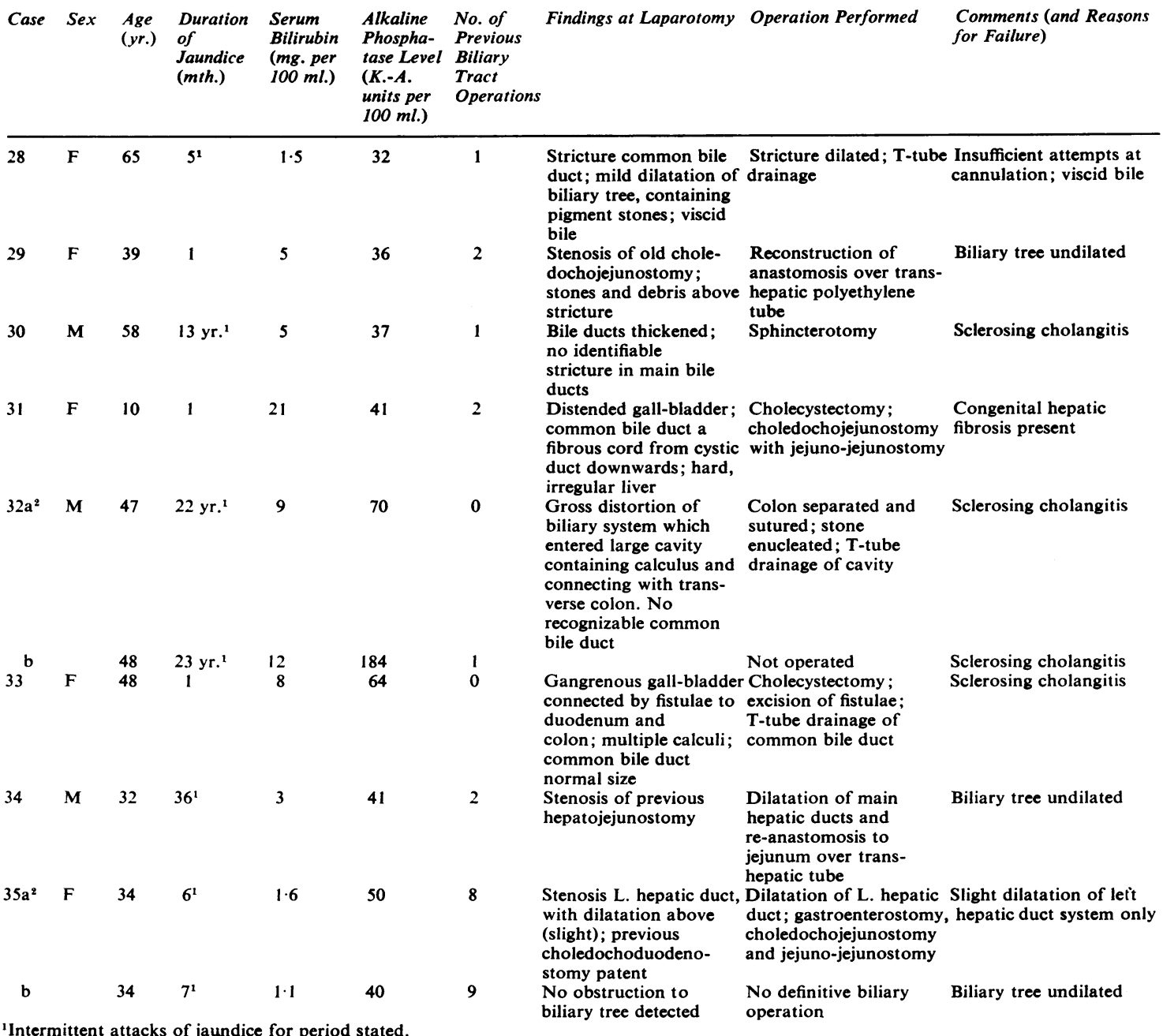

'Intermittent attacks of jaundice for period stated.

${ }^{2}$ Percutaneous cholangiography attempted on two separate occasions

Moderate dilatation of the biliary tree was demonstrated at laparotomy. A stricture of the common bile duct was dilated up and T-tube drainage with biliary lavage instituted. The bile in this patient was extremely viscid and this might have made aspiration through a fine tube impossible. Another patient (case 31) suffered from congenital hepatic fibrosis and the extremely hard liver caused technical difficulty. At laparotomy a stricture of the common bile duct was excised and cholecystectomy and choledocho-jejunostomy with jejuno-jejunostomy were performed.

In six other patients (cases $29,30,32,33,34,35$ ) no significant dilatation of the biliary tree was present.
In case 29 , stenosis of a previous choledocho-jejunostomy was found at laparotomy. Small calculi were present in the common hepatic duct. Choledochojejunostomy was performed using a transhepatic tube as a splint (Smith, 1964). In case 34, the findings were similar, although stones were not present; the same operative procedure was employed. In case 35 (a patient who had undergone eight previous operations), after the initial attempt at cholangiography, laparotomy revealed mild dilatation above a stricture in the left hepatic duct. This was dilated up, and choledocho-jejunostomy, gastro-enterostomy, and jejuno-jejunostomy then performed. Eight months later, after a recurrence of symptoms, 
percutaneous cholangiography was again unsuccessful and on this occasion no stricture or biliary dilatation was detected at laparotomy. Cholangitis in the absence of obstruction was thought probable.

In three patients (cases $30,32,33$ ) the operative cholangiographic and liver biopsy appearances suggested a sclerosing cholangitis. All gave a history strongly suggestive of long-standing gallstones. In case 30 (58-year-old male) biliary colic and jaundice had occurred 13 years earlier, but at cholecystectomy no calculi had been found. The common bile duct at the current operation was thickened and cord-like throughout its length, these changes extending upwards in the hepatic ducts. Operative cholangiography revealed irregular, attenuated biliary radicles. Sphincterotomy was performed. In case 32 (47-yearold male) symptoms had been present for over 20 years. Laparotomy after failed percutaneous cholangiography revealed gross distortion of the biliary system with a large cavity containing a stone, 1 in. in diameter, which was also eroding into the transverse colon. Tags of necrotic gall bladder lay adjacently. No common bile duct could be identified. Liver histology showed typical changes with heavy inflammatory infiltration of portal zones where biliary radicles were scanty or replaced by fibrous tissue. Removal of the stone, and closure of the fistula, with T-tube drainage of the cavity were employed. Following continued symptoms and jaundice, percutaneous cholangiography was again attempted one year later. As no biliary radicle could be cannulated, further operation was not performed. Case 33 (48-year-old female) had been jaundiced for only one month although symptoms suggestive of gall stones dated back 10 years. Laparotomy revealed numerous adhesions and a small gangrenous gall bladder with fistulae to the duodenum and to the colon. Multiple stones were present but the common bile duct was of normal size. Cholecystectomy and excision of fistulae were performed.

\section{COMPLICATIONS}

Haemorrhage from the puncture site in the liver was never severe enough to require transfusion. In one patient (case 20) a collection of about $500 \mathrm{ml}$. of blood was found in the peritoneal cavity at operation but active bleeding had ceased. In other cases only a little blood at the puncture site was visible at laparotomy. There was no instance of biliary peritonitis although a few millilitres of bile were present in the peritoneal cavity on six occasions. During the procedure five patients complained of some pain in the right upper quadrant of the abdomen or in the right shoulder. This was never severe and invariably settled in a short time. In case
32 the transverse colon was inadvertently punctured and in case 34 a loop of small bowel was entered. These errors became obvious immediately after injecting a few millilitres of contrast material under screen control. The catheter was withdrawn in both instances and a fresh one used for the next insertion in a different direction. There were no untoward effects, and, at subsequent laparotomy, the surgeon was unable to detect the site of puncture of these organs.

\section{DISCUSSION}

Percutaneous cholangiography should always be performed in relation to surgery, since successful cannulation of a dilated duct should be followed by surgical relief of the obstruction within a few hours if biliary leakage and peritonitis are to be avoided. For this reason the procedure should never be employed in patients considered unable to withstand operation. Although general anaesthesia has been advocated (Wiechel, 1960) this is usually reserved for unduly young or apprehensive patients. General anaesthesia is essential if the patient cannot or will not hold his breath during introduction of the needle.

The anterior approach is the best for routine use. Others employ a lateral or posterior approach (Housset and Vantsis, 1957; Wiechel, 1960; Prioton, 1960). The posterior approach is said to obviate the risk of blood or bile leaking into the peritoneal cavity since it is not trans-peritoneal (Prioton, 1960). This is a questionable advantage as the posterior or lateral sites are not readily accessible in the event of a complication. When using the anterior approach in a patient who has had previous abdominal surgery, a good track must be made through the scar tissue. Without this preparation, introduction of the soft catheter may prove impossible. In cases with extreme abdominal scarring the lateral approach may be preferable.

Intubation of a duct is achieved by slowly withdrawing and aspirating the catheter until bile is obtained. Aspiration with a needle during insertion has also been advocated (Mandl, 1953; Glenn et al., 1962) but has the disadvantage that a rigid needle must be used, so enhancing the risk of producing a tear in the liver substance. Preliminary aspiration of bile has been recommended (Remolar et al., 1956; Kidd, 1956; Kaplan et al., 1961; Wiechel, 1964) but it is not necessary as bile and contrast medium are readily miscible (Housset and Vantsis, 1957; Wiechel, 1964). The medium may be injected under television fluoroscopic control and the cannula then manipulated until filling of biliary radicles is seen on the screen (Arner et al., 1962; Glenn et al., 
1962). This technique may be helpful where the biliary tree is undilated (Arner et al., 1962).

The two most serious complications of the procedure are intra-abdominal haemorrhage and bile peritonitis, either from leakage from the puncture site or from actual laceration of the liver. Probably the most important factor in avoiding liver injury is the use of a soft catheter after removal of the needle. This obviates the need to prevent extensive or unexpected liver movements by general anaesthesia, or by 'blocking' the ipsilateral phrenic nerves as has been suggested (Varela Fuentes, Bertoni, and Polero, 1957).

Significant haemorrhage occurred in only five patients in a series of 685 percutaneous cholangiograms reviewed by Wiechel (1964). Uncorrected hypoprothrombinaemia was present in the fatal case described by Nurick et al. (1953). Persistent prolongation of prothrombin time by more than two seconds should be a contraindication to the procedure. Significant haemorrhage occurred in one case in the present series. The prothrombin time was normal and chance puncture of a large vessel was probably responsible. Active bleeding had ceased by the time laparotomy was performed and it is unlikely that life would have been endangered.

In the same series of 685 patients bile peritonitis occurred in over 20 patients (Wiechel, 1964). This figure could probably have been much reduced had operation followed the same day in all cases where a cholangiogram demonstrated an obstructive lesion, and bile leaking through the puncture track therefore been avoided. In two or three reported cases where death was attributed to biliary peritonitis, operation had been delayed despite demonstration of an obstructed biliary tree by the investigation (Leger et al., 1953; Zinberg et al., 1965). There were no instances of bile peritonitis in the present series. The practice of leaving the polyethylene catheter in place to decompress the biliary tree while operation is awaited may also prevent biliary leakage. Broad-spectrum antibiotic cover for the procedure and routine culture of bile are of particular importance in cases of biliary stricture where leakage of potentially infected bile and consequent peritonitis or septicaemia is possible.

Small bowel and colon were each punctured on one occasion but without ill effect, and this is generally the case (George et al., 1965). Careful watch should be kept on the patient where laparotomy is not undertaken. Puncture of the gall bladder has also been reported (Kidd, 1956; Varela Fuentes et al., 1957; Santos et al., 1960; Arner et al., 1962). Provided operation is carried out in cases in which an obstructive lesion is demonstrated this should not be serious. In one patient with hepatocellular disease reported by George et al. (1965), on whom operation was not performed despite gall bladder puncture, no untoward effects followed.

The success or failure of percutaneous cholangiography is governed by the degree of dilatation of the intrahepatic biliary radicles, and this in turn is related more to the duration of biliary obstruction than simply to the depth of jaundice. Absence of clinical jaundice does not preclude success, for in 10 instances cholangiograms were obtained when the serum bilirubin level was less than $2 \mathrm{mg} . \%$ (Table I). The serum alkaline phosphatase level, which is a more sensitive index of biliary obstruction, was, however, invariably raised. In eight of nine unsuccessful attempts at cholangiography, subsequent operative cholangiograms revealed an undilated biliary tree. In patients with biliary stricture obstruction is often intermittent or partial and the degree of biliary dilatation variable. As many as 10 attempts at puncture may be necessary before eventual success. This is more than the five attempts suggested as the maximum for the differential diagnosis of jaundice (George et al., 1965). In some patients with biliary stricture the biliary tree is reduced in calibre and the bile ducts are undergoing obliterative fibrosis. Such changes were noted in three patients (cases $30,32,33$ ) in whom cholangiography was unsuccessful.

The gravity of biliary stricture needs no stressing: 35 to $40 \%$ of patients who have undergone repair operations die within three or four years and with consecutive attempts at repair the chances of eventual cure become more and more remote (Maingot, 1964). Knowledge of the exact site and extent of the stricture is invaluable, especially in an operation field which is frequently scarred by previous attempts at biliary repair. Operating time is greatly reduced and the chances of further damage to other parts of the biliary tree are lessened. A decision about the nature of the reconstruction to be undertaken can often be made beforehand. A simpler operation than had been expected may- be possible. Thus in two cases in the present series complete reconstruction of a previous anastomosis was avoided and a simple dilatation sufficed as no scar tissue was apparent. The procedure is perhaps of greatest value in patients with a stricture high in the biliary tree, where a knowledge of the line of direction of the main ducts is invaluable when dilators and tubes are to be passed. In other patients the demonstration of multiple pathologies such as stricture and stones (shown in ten cases) or of multiple strictures (shown in four cases) is of value.

Occasionally, when percutaneous cholangiography reveals a slightly or undilated biliary tree with little or no obstruction, operative intervention may be 
avoided altogether. This is a rare occurrence, however, and only one example can be quoted from the present series. In these circumstances it is more usual to find that films cannot be obtained. When this is the case a decision about the advisability of operation must be based on the whole clinical picture and biochemical investigations. In patients with a stricture the clinical history, however, is usually fairly typical with attacks of jaundice or pain or of cholangitis. Laparotomy is then undertaken irrespective of the cholangiographic result.

\section{SUMMARY}

Percutaneous transhepatic cholangiography, by means of a flexible polyethylene catheter, successfully outlined the biliary tree in 29 out of 39 instances in patients with strictures of the bile ducts. No serious complication was encountered. Twenty-five patients had already undergone operations for biliary reconstruction and in seven cases the stricture was particularly high, involving either the junction of right and left main hepatic ducts or the ducts themselves. In no case had the biliary tree been satisfactorily outlined by oral or intravenous cholangiography. In all cases except one, operation was performed within two hours after the procedure, and the cholangiographic findings confirmed. The information obtained beforehand about the biliary anatomy was of inestimable value to the surgeon both in the planning and execution of the operation.

In nine instances where percutaneous cholangiography was unsuccessful, subsequent laparotomy revealed no significant biliary dilatation in eight, and in three of these patients there was evidence of sclerosing cholangitis.

The use of a flexible catheter, and the performance of the investigation only as a preliminary to surgical exploration have made this technique safe as well as invaluable in patients with biliary stricture.

We wish to thank Mr. Rodney Maingot for permission to include details of his patients in the present series. Our thanks are also due to the many clinicians who referred the cases. We are also grateful to Miss Hollis, superintendent radiographer, and her staff, to Professor D. N. Baron for the biochemical investigations, and to Mrs. A. Birbeck, medical artist, and Mr. R. Phillips of the photography department of the Royal Free Hospital for their painstaking work. One of us (J.G.W.) was in receipt of a grant from the Ingram trust.

\section{REFERENCES}

Arner, O., Hagberg, S., and Seldinger, S. I. (1962). Percutaneous transhepatic cholangiography: puncture of dilated and nondilated bile ducts under roentgen television control. Surgery, 52, 561-571.

Darmaillacq, R., and Régnier, (1954). Hémorragie intrapéritonéale mortelle après cholangiographie transhépatique pour ictère par rétention. Arch. Mal. Appar. dig., 43, 631.

Elkington, S. G., and Bernstein, D. C. (1964). Percutaneous transhepatic cholangiography. Brit. med. J., 2, 733-735.

Fernström, I., and Seldinger, S. I. (1956). Cholangiografi efter perkutan gallgångspunktion. Nord. Med., 55, 344.

Flemma, R. J., Schauble, J. F., Gardner, C. E., Jr., Anlyan, W. G., and Capp, M. P. (1963). Percutaneous transhepatic cholangiography in the differential diagnosis of jaundice. Surg. Gynec. Obstet., 116, 559-568.

George, P., Young, W. B., Walker, J. G., and Sherlock, S. (1965). The value of percutaneous cholangiography. Brit.J. Surg., 52, 779-783

Glenn, F., Evans, J. A., Mujahed, Z., and Thorbjarnarson, B. (1962). Percutaneous transhepatic cholangiography. Ann. Surg., 156, 451-462.

Housset, E., and Vantsis, G. (1957). La cholangiographic transperiéto-hépatique. Presse méd., 65, 772-773.

Huard, P., and Do-Xuan-Hop (1937). La ponction transhépatique des canaux biliaires. Bull Soc. méd.-chir. Indochine, 15, 1090-1100.

Isley, J. K., Jr., and Schauble, J. F. (1962). Interpretation of the percutaneous transhepatic cholangiogram. Amer. J. Roentgenol., 88, 772-777.

Kaplan, A. A., Traitz, J. J., Mitchel, S. D., and Block, A. L. (1961). Percutaneous transhepatic cholangiography. Ann. intern. Med., 54, 856-869.

Kidd, H. A. (1956). Percutaneous transhepatic cholangiography. Arch. Surg., 72, 262-268.

Leger, L., Zara, M., and Wargnier, M. (1953). Cholangiographie et drainage biliaire par ponction trans-pariéto-hépatique. Arch. Mal. Appar. dig., 42, 967-978.

Maingot, R. (1964). In Surgery of the Gall Bladder and Bile Ducts, edited by R. Smith and S. Sherlock. Butterworths, London.

Mandl, F. (1953). Zur präoperativen cholangiographie. Wien. klin. Wschr., 65, 876-877.

Nurick, A. W., Patey, D. H., and Whiteside, C. G. (1953). Percutaneous transhepatic cholangiography in the diagnosis of obstructive jaundice. Brit. J. Surg., 41, 27-30.

Prioton, J-B. (1960). La cholangiographie par ponction extrapéritonéale du foie. Presse méd., 68, 2308-2311.

Redington, J. C., Fitzgerald, W. T., and Knight, W. A., Jr. (1957). Percutaneous transhepatic cholangiography. Gastroenterology, 33, 273.

Remolar, J., Katz, S., Rybak, B., and Pellizari, O. (1956). Percutaneous transhepatic cholangiography. Ibid., 31, 39-46.

Santos, M., Figueroa, L., and López, O. (1960). Percutaneous transhepatic cholangiography in the diagnosis of posthepatic jaundice. Surgery, 48, 295-303.

Shaldon, S., Barber, K. M., and Young, W. B. (1962). Percutaneous transhepatic cholangiography. A modified technique. Gastroenterology, 42, 371-379.

Smith, R. (1964). Hepaticojejunostomy with transhepatic intubation. A technique for very high strictures of the hepatic ducts. Brit. J. Surg., 51, 186-194.

Stiris, G. (1962). Perkutan, transhepatisk cholangiografi. T. norske Laegeforen., 82, 443-445.

Varela Fuentes, B., Bertoni, C., and Polero, J. (1957). La colangiografia por puncion hepatica. Pren. méd. argent., 44, 2873-2883.

Wiechel, K-L. (1960). Percutan transthoracal transhepatisk cholangiografi. Opusc. med. (Stockh.), 5, 287-289.

(1964). Percutaneous transhepatic cholangiography. Technique and application. Acta chir. scand., suppl., 330.

Zinberg, S. S., Berk, J. E., and Plasencia, H. (1965). Percutaneous transhepatic cholangiography: its use and limitations. Amer. J. dig. Dis., 10, 154-169. 